\title{
PSYCHOLOGICAL CONDITION CONSTRAINTS OF LEARNING PARTICIPANTS IN STUDYING ENGLISH (Study at Learning Group of Package " $C$ " in Community Learning Center / Pusat Kegiatan Belajar Masyarakat (PKBM) Nugraha Mandiri Cimahi City - West Java Province)
}

\author{
Sudiyono ${ }^{1}$ \\ ${ }^{1}$ IKIP Siliwangi \\ ${ }^{1}$ sudiyonostkipslw@gmail.com
}

\begin{abstract}
This study reviewed the condition of learning participants' at the study group of package "C" equivalent to SMA / SMK in the Community Learning Center (PKBM) Nugraha Mandiri which is located at Jalan Sawah Lega number 70 A, Cipageran Village, North Cimahi District, Cimahi City - West Java Province. The condition of learning participants in this research were psychological constraints. Psychological constraints in this paper were limited only to : (a) interest in learning; (b) learning motivation; (c) intelligence; and (d) learning activities of the learning participants population. The sample taken for this study was 32 people. The study was conducted using observation techniques, document studies, and interviews. While the research approach is a qualitative descriptive approach. The results of the research show that more than $50 \%$ of the learning participants face psychological factor constraints, and further this condition affects their learning behavior.
\end{abstract}

Keywords: Learning Participants, Psychological Constraints, English Lessons

\section{INTRODUCTION}

Learning activities can be carried out in different paths and levels. Learning activities in Indonesia when viewed from the path can be carried out formally, non-formally, and informally. Meanwhile, when viewed from the level, education in Indonesia starts from the pre-primary level to the university level. (UURI Number 20 of 2003). One pathway for non-formal education whose graduates are recognized / equated with graduates of formal education pathways is the A / B / C Equality Package Program or equivalent to SD / MI; SMP / MTs; SMA (SMK) / MA.

Students' learning behavior is much influenced by various factors that originate from within and from outside each other's personal self. Learning behavior like this almost covers all the subject matter students learn both science and social subjects, including language subjects, specifically English subjects. English subjects are subjects taught to students ranging from preschool level to college level. As for the non-formal education pathway this subject can be learned through courses, tutoring, study groups and other similar forms.

Psychological factors that influence students' learning behavior (in the context of this paper is behavioral learning in English) are factors that generally originate in students' personal self. This factor consists of interest in learning; motivation to learn; students' intelligence; and 
students' activities (Rakhmat, J., \& Surjaman, 1999). According to Mangal (2007) as cited in (Saswandi, 2015) interest is the central force that drives the whole machinery of teaching learning process. It means, with have an interest student will more focus and easy to understand the material that given by the teacher. Big interest will give influence on students' activity, because the students' interest will be doing something that interested for them, in this case is an interest in learning. (Harmer, 2007) states "In fact, learning is the human activity which least needs manipulation by others. Most learning is not the result of instruction. It is rather the result of unhampered participation in a meaningful setting." meanwhile, interest helps in overcoming unusual or early arrival or frequent repetition of plateaus in learning. They also give enough strength to an individual to resist fatigue and avoid failure. So far, indicators of learning interest as cited from (Medina Aulia, 2019) consisting of: diligent in learning; tough in learning; diligent in doing tasks; have a study schedule; and discipline in learning.

Robin (1998, p. 168) as cited in (Sudiyono, 2010), stated that motivation is willingness to exert high level of effort toward organizational goal, conditioned by the effort's ability to satisfy some individual need. In context of learning motivation, refers to the statement, is ones' willingness to achieve higher level of learning achievement. While the indicators of learning motivation consist of: ideals; students' ability; physical and mental condition of students; environmental conditions and efforts made by the teacher (Mulyana, 2019).

Malleability of intelligence refers to beliefs about the nature - and particularly the flexibilityof intelligence. While intelligence has been much studied within the fields of biology, genetics, psychology, and the learning sciences, there is no universally accepted definition of what exactly constitutes "intelligence." (The Charles A. Dana Center, 2020). Students' intelligence is about ability of students to capture lessons, to understanding the lessons, and their ability to explain the lessons they learned to friends and teachers. The indicators of students' intelligence in learning empirically can be seen from the way students capture lessons; the way students understand lessons; and the way they explain the subject matter they learned to other fellow students, as well as to the teacher.

While students' learning activities include, among others: activeness in participating in learning activities; activeness in finding references; activeness in 'asking the teacher; activeness in practice

Tabel 1. Indicator of Psychological Factors

\begin{tabular}{|c|c|c|c|}
\hline \multicolumn{4}{|c|}{\begin{tabular}{|l} 
Psychological Factors \\
\end{tabular}} \\
\hline $\begin{array}{c}\text { Indicator of } \\
\text { Learning Interest }\end{array}$ & $\begin{array}{l}\text { Indicator of } \\
\text { Motivation }\end{array}$ & $\begin{array}{c}\text { Indicators of } \\
\text { Intelligence }\end{array}$ & $\begin{array}{c}\text { Indicators of } \\
\text { Activities }\end{array}$ \\
\hline $\begin{array}{ll}\text { - } & \begin{array}{l}\text { Diligent in } \\
\text { learning; }\end{array} \\
\text { - } & \text { Tough in } \\
\text { learning; } \\
\text { - } & \text { Diligent in } \\
\text { doing tasks; } \\
\text { - Have a study } \\
\text { schedule; } \\
\text { and } \\
\text { - Discipline in } \\
\text { learning. }\end{array}$ & 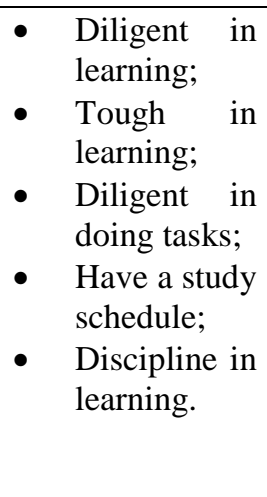 & $\begin{array}{l}\text { - The way students } \\
\text { capture lessons; } \\
\text { The way students } \\
\text { understand } \\
\text { lessons; } \\
\text { The way they } \\
\text { explain the } \\
\text { subject matter } \\
\text { they learned to } \\
\text { other fellow } \\
\text { students, as well } \\
\text { as to the teacher. }\end{array}$ & 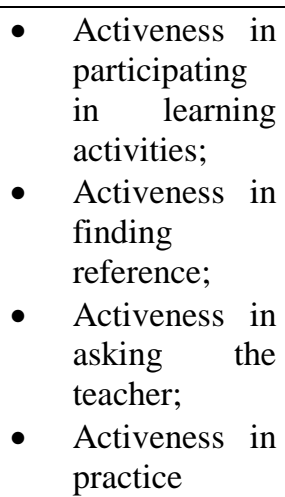 \\
\hline
\end{tabular}




\section{Sources: Eni Endriani, 2011. Aina Mulyana, 2019.}

(http://generusindonesia-wordpress.com)

The purpose of writing this paper is to get an overview of the profile and learning activities carried out in the " $\mathrm{C}$ " Package Equally Program in the Community Learning Center (PKBM) of Nugraha Mandiri Cimahi in the Academic Year 2018-2019.

Another goal is to get an idea of how the composition of the English learning participants among who have constrained by psychological factors and the normal ones in the " $\mathrm{C}$ " Equality Package Program in PKBM Nugraha Mandiri Academic Year 2018-2019.

\section{METHOD}

This research was conducted at PKBM Nugraha Mandiri as the organizer of the "C" Package Equality Program Academic Year 201-2019. Population is the whole research subject (Suharsimi, 2006). In this study the population used was the "C" Equality Package Program in PKBM Nugraha Mandiri consisting of 32 of X class students who were at the same time the research sample. Because the population in this study is less than 100, the sample is the entire population. (Suharsimi, 2006) states that as an alternative, if the subject is less than 100 it is better to take it all so that the research is a population research.

The study was conducted from March to May 2019. The method used in this study is descriptive qualitative, while the steps for collecting and processing data are as follows: (1) conducting a preliminary study; (2) conduct document studies, observations and interviews; (3) do data processing; activities conducted at this institution was obtained by conducting observations and interviews with the chairman of PKBM Nugraha Mandiri (Mr H.A. Sambas, S.Ag), PKBM Nugraha Mandiri's profile covering a brief history, management, facilities and infrastructure, and number of study residents.

Learning activities studied are limited to only include: learning time in English subjects; time for learning activities; number of meetings; learning methods; competence of English tutors; infrastructure; and textbooks.

Meanwhile data collection related to learning behavior of English learning students is obtained by conducting questions to all learning participants whose core is to obtain information about the relevance of psychological factors to their learning behavior. Psychological factors are derived into a number of indicators, namely; learning interest, learning motivation, intelligence level, and level of students' activity. From each of these indicators, it is further reduced to a number of sub-indicators.

The procedure for data processing is done by (1) selecting data that has been netted; (2) classifying selected data; (3) compiling data into tables; (4) interpret the collected data.

\section{RESULTS AND DISCUSSION}

\section{Results}

\section{Overview of the Profile and Learning Activities}

From the results of observations and interviews conducted by researcher with the Chairperson of PKBM Nugraha Mandiri, the findings are as follows: (1) PKBM profile; (2) PKBM management; (3) Learning facilities and infrastructure; The brief profile of PKBM Nugraha Mandiri can be known as follows:

\section{Tabel 2. Brief Profile of PKBM NugrahaMandiri}




\begin{tabular}{cll}
\hline 1 & Name of PKBM & NUGRAHA MANDIRI \\
\hline 2 & Address of PKBM & $\begin{array}{l}\text { Jalan Sawah Lega no. 70A, RT.03/02, Cipageran - Cimahi Utara, } \\
\text { Kota Cimahi Kode Pos 40511, Provinsi Jawa Barat. }\end{array}$ \\
\hline 3 & Telphon/HP & $022664892 / 082115392443$ \\
\hline 4 & $\begin{array}{l}\text { Registration number } \\
\text { Institution NILM }\end{array}$ & of \\
\hline 5 & Tax no./NPWP & 14.1964382 \\
\hline 6 & PKBM Holder & Yayasan Nugraha Mandiri \\
\hline 7 & Notarial & Romy Jayaprana, SH, No. 18, Tgl. 28/10/2011 \\
\hline 8 & Date of PKBM born & 01 Juni 2011 \\
\hline 9 & Coach of PKBM & DISDIKPORA PEMKOT CIMAHI \\
\hline 10 & Sum of students of 2018- & 1. Paket A/setara SD 29 warga belajar \\
& 2019 school year & 2. Paket B/setara SLTP 27 warga belajar \\
& & 3. Paket C/setara SLA/SMK 32 warga belajar
\end{tabular}

Source : Profil PKBM Nugraha Mandiri 2018-2019, re-arranged.

PKBM Nugraha Mandiri Management as the organizer of the " $\mathrm{C}$ " Equality Package Program already has complete management with a chairman, secretary and treasurer as well as a good administrative system. The administrative system in PKBM Nugraha Mandiri consists of organizational structure; details of the manager's duties; list of management / member arrangements; work plan; PKBM signboard; report on the implementation of activities; attendance list of managers; attendance list of tutors ; attendance list of study residents; lesson schedule; list of conditions for students.

Learning activities and learning support facilities: the time of the "C" Package Equality Program learning activities at PKBM Nugraha Mandiri is held every Saturday and Sunday starting at 07.30 until $13.30 \mathrm{WIB}$. The time for meeting English learning activities is 90 minutes per meeting / week. The total number of participants was 32 people, but in each meeting there were usually some people who were absent because of something and other things experienced by the learning participants. The learning method applied for English subjects is the teacher center approach. Qualifications of tutors who teach English subjects in the "C" Package Equality Program at PKBM Nugraha Mandiri have a Bachelor's qualification in English Language and Literature Education. Facilities and infrastructure related to learning activities include learning sets and chairs for 20 sets; management tables and chairs 6 sets; guest chair 1 set; blackboard 4 pieces; bookcase 2 pieces; 3 pieces lockers; 1 piece laptop. While the textbook used is in the form of 10 general knowledge books; 10 titles of religious books; skill book 5 titles; sports book 3 titles; Module Package A is not available, Package B Module 38 sets, Module Package C 30 sets.

\section{Composition of the English Learning Participants}

The results of data processing show that each indicator of psychological factors derived into several sub-indicators related to the learning behavior of PKBM Nugraha Mandiri learning participants is as follows:

Tabel 3. Indicators of Learning Interest

\begin{tabular}{llcc}
\hline No. & Indicator of Learning Interest & $\begin{array}{c}\text { Sum of } \\
\text { learning } \\
\text { participants }\end{array}$ & $\begin{array}{c}\text { Percentage } \\
(\%)\end{array}$ \\
\hline 1 & Diligent in learning; & 25 & $78 \%$ \\
\hline 2 & Tough in learning; & 20 & $62,5 \%$
\end{tabular}




\begin{tabular}{llcc}
\hline 3 & Diligent in doing tasks; & 20 & $62,5 \%$ \\
\hline 4 & Have a study schedule; and & 16 & $50 \%$ \\
\hline 5 & Discipline in learning. & 25 & $78 \%$ \\
\hline & Total Average & $\mathbf{2 1}$ & $\mathbf{6 6 \%}$
\end{tabular}

Tabel 4. Indicators of Motivation

\begin{tabular}{llcc}
\hline No. & Indicator of Motivation & $\begin{array}{c}\text { Sum of } \\
\text { learning } \\
\text { participants }\end{array}$ & $\begin{array}{c}\text { Percentage } \\
(\mathbf{\%})\end{array}$ \\
\hline 1 & Diligent in learning; & 16 & $50 \%$ \\
\hline 2 & Tough in learning; & 10 & $31 \%$ \\
\hline 3 & Diligent in doing tasks; & 32 & $100 \%$ \\
\hline 4 & Have a study schedule; & 15 & $49 \%$ \\
\hline 5 & Discipline in learning. & 32 & $100 \%$ \\
\hline & Total Average & $\mathbf{2 1}$ & $\mathbf{6 6 \%}$
\end{tabular}

Tabel 5. Indicators of Intelligence

\begin{tabular}{llcc}
\hline No. & \multicolumn{1}{c}{ Indicators of Intelligence } & $\begin{array}{c}\text { Sum of } \\
\text { learning } \\
\text { participants }\end{array}$ & $\begin{array}{c}\text { Percentage } \\
(\mathbf{\%})\end{array}$ \\
\hline 1 & The way students capture lessons; & 6 & $19 \%$ \\
\hline 2 & The way students understand lessons; & 5 & $16 \%$ \\
\hline 3 & $\begin{array}{l}\text { The way they explain the subject matter they } \\
\text { learned to other fellow students, as well as to } \\
\text { the teacher. }\end{array}$ & 2 & $6 \%$ \\
\hline & Total Average & $\mathbf{4}$ & $\mathbf{1 3 \%}$
\end{tabular}

Tabel 6. Indicators of Activities

\begin{tabular}{llccc}
\hline No. & Indicators of Activities & $\begin{array}{c}\text { Sum of } \\
\text { learning } \\
\text { participants }\end{array}$ & $\begin{array}{c}\text { Percentage } \\
\text { (\%) }\end{array}$ \\
\hline 1 & $\begin{array}{l}\text { Activeness in participating } \\
\text { activities; }\end{array}$ & 8 & $25 \%$ \\
\hline 2 & Activeness in finding reference; & 16 & $50 \%$ \\
\hline 3 & Activeness in asking the teacher; & 9 & $28 \%$ \\
\hline & Activness in practice & & \\
\hline & Total Average
\end{tabular}

Tabel 7. Indicators of Psychology Factor

\begin{tabular}{llcc}
\hline No. & Indicators of Psychological Factor & $\begin{array}{c}\text { Sum of } \\
\text { learning } \\
\text { participants }\end{array}$ & $\begin{array}{c}\text { Percentage } \\
(\boldsymbol{\%})\end{array}$ \\
\hline 1 & Indicator of Learning Interest & 21 & $66 \%$ \\
\hline & Indicator of Motivation & 21 & $66 \%$ \\
\hline 3 & Indicators of Intelligence & 4 & $13 \%$ \\
\hline 4 & Indicators of Activities & 11 & 34
\end{tabular}




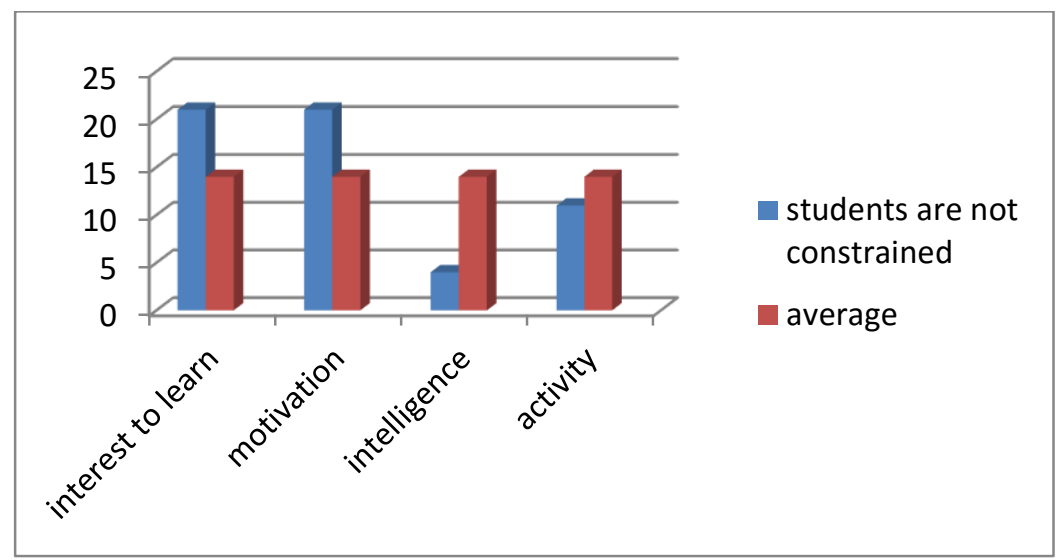

Gambar 1. Graph of Non Psychological Constrained Learning Participants

\section{Discussion}

From the findings in the field, it can be explained several things related to the results of research conducted by the author, first related to the situation of PKBM Nugraha Mandiri as the organizer of the "C" Package Equality Program equivalent to SMA / SMK; the second is related to psychological factors and learning behavior of English learning participants.

\section{Profile and Learning Activities}

The profile of PKBM Nugraha Mandiri as the organizer of the " $C$ " Equality Package Program is well known to the community besides its existence for quite a long time, this institution is very concerned about the problems associated with the establishment of an organization that engages in education, especially non-formal education this is the Package Learning Group Program. Administrative requirements that are sufficiently good are indicated by the existence of a complete institutional profile; good management; complete administrative system; and a complete division of tasks.

Learning activities at this institution can also be assessed well because the learning time has been arranged neatly, the tutor has a Bachelor qualification (S1) in accordance with the subject matter taught; sufficient learning facilities and infrastructure; good textbooks / modules.

\section{Psychological Factors and Learning Behavior}

The psychological factors in this paper referred to psychological factors that can influence the learning behavior of the learning population, especially in learning English subjects. This psychological factor consists of several sub-factors, namely: interest in learning, learning motivation, intelligence, and learning activities. Interest in learning, from the table, it can be seen that the learning citizens of PKBM Nugraha Mandiri who are categorized as having good learning interests are 21 people from a total sample of 32 people, or about $66 \%$ of the total sample. This gives an indication that more than half of the learning population has a good interest in learning.

Learning motivation, from the table, can be seen that the learning citizens of PKBM Nugraha Mandiri which are categorized as having good learning motivation are 21 people from a total 
sample of 32 people, or about $66 \%$ of the total sample. This gives an indication that more than half of the learning population has good learning motivation.

Learning motivation, from the table, can be seen that the learning citizens of PKBM Nugraha Mandiri which are categorized as having good learning motivation are 21 people from a total sample of 32 people, or about $66 \%$ of the total sample. This gives an indication that more than half of the learning population has good learning motivation.

The learning activities of the participants from the table, can be seen that the PKBM Nugraha Mandiri learning citizens who are categorized as having good learning activities are as many as 11 people from a total sample of 32 people, or about $34 \%$ of the total sample. This gives an indication that less than half of the learning population have good interest in learning.

From the four indicators of psychological symptoms experienced by the students as shown in the table above, this can illustrate that on the average number of learning people there are as many as 14 people or about $46 \%$ of the total number of study residents.

\section{CONCLUSION}

From the research findings on the psychological constraints faced by learning participants of the " $C$ " Equality Package Program equivalent to high school/ vocational school in the 20182019 academic year, it can be concluded that more than half of all learning participants experience problems with psychological problems in taking English lessons. This is evident from the number of 32 study residents that only 14 study residents were not constrained by psychological factors.

\section{ACKNOWLEDGMENTS}

All praise to Allah for helping the author to finish this research. The writer wants to express his gratitude to his beloved family and best friends who had supported him in completing this research.

\section{REFERENCES}

Hapsari, M. A. (2019). The Correlation Study Between Students'self-Confidence And Learning Style Towards Their Speaking Ability At The Second Semester Of English Language Education In Iain Surakarta In The Academic Year 2018/2019 (Doctoral Dissertation, Iain Surakarta).

Harmer, J. (2007). The Practice Of English Language Teaching. Harlow: Pearson Longman. Medina Aulia, H. (2019). The Correlation Study Between Students'self-Confidence And Learning Style Towards Their Speaking Ability At The Second Semester Of English Language Education In Iain Surakarta In The Academic Year 2018/2019. Doctoral Dissertation, Iain Surakarta).

Nomor, U. U. R. I. (20). Tahun 2003 Tentang Sistem Pendidikan Nasional. 2003. Bandung: Citra Umbara.

Pkbm Nugraha Mandiri, 2019. Profil Lembaga Pusat Kegiatan Belajar Masyarakat (Pkbm) Nugraha Mandiri. Cimahi: Pkbm Nugraha Mandiri.

Rakhmat, J., \& Surjaman, T. (1999). No Title. In Psikologi Komunikasi. Remaja Rosdakarya. Saswandi, T. (2015). Teaching Style And Students' Interest In Learning English. Jurnal Penelitian Universitas Jambi: Seri Humaniora, 17(1).

Sudiyono. (2012). Pengaruh Motivasi Kerja, Kompetensi Guru, Dan Kompensasi Terhadap Kinerja Guru Non Pns Pada Madrasah Tsanawiyah Di Lingkungan Departemen Agama Kantor Kota Cimahi. Bandung: Stie Pasundan. 
Suharsimi, A. (2006). Prosedur Penelitian Suatu Pendekatan Praktik. Jakarta: Rineka Cipta. 